\title{
STUDI AWAL PERIKANAN PARI KEKEH (Rhynchobatus sp.) DAN PARI KIKIR (Glaucostegus sp.) DI PERAIRAN UTARA JAWA TENGAH
}

\author{
Dwi Putra Yuwandana ${ }^{1}$, Susan Agustina ${ }^{2}$, Mahyuddin Bahi Haqqi ${ }^{2}$ dan Benaya Meitsari Simeon ${ }^{3}$ \\ ${ }^{1}$ Departemen Pemanfaatan Sumberdaya Perikanan, FPIK, Institut Pertanian Bogor \\ Jl. Agatis Kampus IPB Dramaga Bogor, 16680 \\ ${ }^{2}$ Rekam Nusantara Foundation, Bogor \\ Jl. Sempur No.35, RT.03/RW.01, Sempur, Kecamatan Bogor Tengah, Kota Bogor, Jawa Barat 16129 \\ ${ }^{3}$ Wildlife Conservation Society - Indonesia Program \\ Jl. Malabar 1 No.11, RT.01/RW.01, Babakan, Kecamatan Bogor Tengah, Kota Bogor, Jawa Barat 16128 \\ E-mail: dwiputrayuwandana@gmail.com
}

\begin{abstract}
ABSTRAK
Pari kekeh dan pari kikir merupakan salah satu komoditas perikanan di Indonesia. Di sisi lain, kedua kelompok pari ini masuk ke dalam daftar merah International Union for Conservation of Nature and Natural Resources (IUCN) sebagai spesies ikan yang terancam punah karena populasinya terus menurun dan kerusakan habitat mengancam populasinya. Masuknya kedua pari ini ke dalam apendiks II Convention on International Trade in Endangered Species of Wild Fauna and Flora (CITES) menuntut pengelolaan perikanan untuk menjamin kelangsungan populasinya di alam. Informasi mengenai perikanan pari kekeh dan pari kikir ini masih sangat minim, maka perlu kajian mengenai perikanan ini untuk dasar pengelolaan ke depan. Kajian ini bertujuan untuk mengetahui kondisi umum perikanan pari kekeh dan pari kikir di Jawa Tengah dan tangkapan rata-rata pari kekeh dan pari kikir per trip. Pengambilan data dilakukan pada bulan Mei-Juli 2019 di Pelabuhan Perikanan Pantai (PPP) Tegalsari Tegal, PPP Bajomulyo Pati dan PPP Tasik Agung Rembang. Metode pengambilan data yang dilakukan yaitu perlingkupan kegiatan perikanan pari kekeh dan pari kikir dan pencatatan aktivitas pendaratan. Analisis yang dilakukan yaitu analisis spesies dan ratarata tangkapan per trip (CPUE). Selama penelitian diperoleh 202 trip kapal mendaratkan ikan pari kekeh dan pari kikir di tiga lokasi pendaratan. Ikan pari ini merupakan hasil tangkapan sampingan dari armada penangkapan ikan cantrang dengan ukuran 10-150 GT. Hasil analisis menunjukkan terdapat 6 spesies pari kekeh dan pari kikir yang didaratkan dan rata-rata hasil tangkapan pari kekeh dan pari kikir PPP Tegalsari sebesar 10,3 ekor/trip, PPP Bajomulyo sebesar 9,13 ekor/trip dan PPP Tasikagung sebesar 3,56 ekor/trip yang artinya jenis ikan ini cukup intensif tertangkap oleh armada penangkapan ikan cantrang.
\end{abstract}

Kata kunci: CITES; IUCN; Pari Kekeh; Pari Kikir; Pantura.

\section{PRELIMINARY STUDY OF WEDGEFISH (Rhynchobatus sp.) AND GIANT GUITARFISH (Glaucostegus sp.) IN JAVA SEA OF CENTRAL JAVA}

\begin{abstract}
Wedgefish and giant guitarfish are one of the fisheries commodities in Indonesia. Moreover, these groups are listed on the IUCN red list as critically endangered species because their population continues to decline and habitat loss threatens its population. Both of these groups are listed into CITES appendix II, which is mean the trade between countries should be managed. Information regarding its fisheries still lack, hence it would be necessary to study these fisheries for the basis of future management. This study aims to understand fisheries condition of wedgefish and giant guitarfish in Central Java. Data was collected in May-July 2019 at Tegalsari Coastal Fishing Port (PPP), Bajomulyo Coastal Fishing Port and Tasik Agung Coastal Fishing Port. The data collection methods were scoping and landing monitoring. We conducted species identification and analyzed average catch per trip (CPUE). We found 202 trips landing wedgefish and giant guitarfish from three landings spot. Both group were by-catch of the cantrang fishing boats with a size of $10-150 \mathrm{GT}$. The analysis showed that there were 6 species of wedgefish and giant guitarfish landed and the average catch of wedgefish and giant guitarfish of PPP Tegalsari was 10.3 fish/trip, PPP Bajomulyo was 9.13 fish/trip and PPP Tasikagung was 3.56 fish/trip which means this type of rays is quite intensively caught by the cantrang fishing boats.
\end{abstract}

Key words: CITES; IUCN; Wedgefish; Giant Guitarfish; Pantura.

\section{PENDAHULUAN}

Indonesia merupakan negara produsen dan penangkap hiu dan pari (Kelas Chondrichthyans) terbesar di dunia dan negara eksportir hiu dan pari terbesar ketiga di dunia setelah Negara China dan Thailand. Rata-rata produksi hiu dan pari di Indonesia sebesar 106.034 ton/tahun atau sekitar $13 \%$ dari total produksi hiu dan pari di dunia pada tahun 2000 hingga 2011 (Dent \& Clarke, 2015). Produksi dalam negeri didominasi oleh produksi pari yang mencapai $60 \%$, dimana pari kekeh dan pari kikir masuk ke dalamnya (Direktorat Jenderal Perikanan Tangkap, 2016).
Pari kekeh (Rhinidae) dan pari kikir (Glaucostegidae) merupakan salah satu ikan dari kelas Chondrichthyans yang termasuk ke dalam kelompok ordo Rhinopristiformes. Selain dua kelompok tersebut ordo Rhinopristiformes terdiri dari kelompok Guitarfish (Rhinobatos spp.) dan Sawfish (Pristis spp.). Dari keempat kelompok ikan pari tersebut, Pari Gergaji/Sawfish (Pristis spp.) telah memiliki status perlindungan penuh sejak tahun 1999 berdasarkan Peraturan Pemerintah No. 7 tahun 1999 tentang Pengawetan Jenis Tumbuhan dan Satwa. Regulasi perilindungan pari tersebut kemudian diperbaharui pada tahun 2018 melalui Peraturan Menteri Lingkungan Hidup dan Kehutanan Nomor P. 
106/MNLHK/SETJEN/KUM.1/2018 tentang Jenis Tumbuhan dan Satwa yang Dilindungi.

Pari kekeh dan pari kikir merupakan salah satu komoditas perikanan di Indonesia. Di sisi lain, kedua kelompok pari ini dikategorikan oleh The International Union for Conservation of Nature (IUCN) sebagai spesies ikan yang terancam punah (Critically Endangered / CR) karena populasinya terus menurun dan kerusakan habitat mengancam populasinya. Kedua kelompok pari ini juga masuk ke dalam apendiks II CITES pada Agustus 2019, yang artinya perdagangannya antar negara harus dikelola untuk menjamin pemanfaatannya tidak mengancam kelestariannya (Rahman et al., 2017).

Indonesia sebagai produsen dan penangkap ikan hiu dan pari tersebar di dunia, memiliki peranan penting dalam menjaga kelestarian pari kekeh dan pari kikir di alam sebagai sumberdaya yang berkelanjutan. Diperkirakan terdapat 5 spesies pari kekeh (Rhynchobatus australiae, Rhynchobatus springeri, Rhynchobatus laevis, Rhynchobatus palpebratus dan Rhina ancylostoma) dan 2 spesies pari kikir (Glaucostegus typus dan Glaucostegus thouin) yang habitatnya tersebar di hampir seluruh perairan Indonesia (Simeon et al., 2019). Di Indonesia jenis pari ini dimanfaatkan untuk konsumsi lokal dan sebagai komoditas ekspor (Muttaqin et al., 2018).

Hampir seluruh bagian tubuh dari jenis ikan ini dimanfaatkan oleh masyarakat seperti sirip, daging, kulit, tulang bahkan isi perutnya. Bagian sirip dari pari kekeh dan pari kikir merupakan komoditas untuk ekspor yang memiliki nilai ekonomis yang paling tinggi dibandingan dengan bagian tubuh lainnya maupun dibandingkan dengan sirip jenis hiu pari lainnya, karena sirip jenis pari ini memiliki ukuran sirip yang paling besar dibanding sirip jenis hiu pari lainnya (Muttaqin et al., 2018).

Informasi mengenai perikanan pari kekeh dan pari kikir ini masih sangat minim, maka perlu kajian mengenai perikanan ini untuk dasar pengelolaan ke depan. Daerah penangkapan utama untuk komoditas kedua kelompok pari ini tersentra di WPP 711, 712, dan 713 (DJPT, 2016), dengan pelabuhan pendaratan di Pantai Utara Jawa. Jawa Tengah sebagai provinsi dengan pelabuhan perikanan yang terletak di Pantai Utara Jawa menjadi lokasi yang tepat untuk kajian kedua pari ini. Penelitian ini bertujuan untuk mengetahui kondisi umum perikanan pari kekeh dan pari kikir di Jawa Tengah dan tangkapan rata-rata pari kekeh dan pari kikir per trip (CPUE).

\section{METODE}

Penelitian ini dilakukan pada bulan Mei Juli 2019 di Pelabuhan Perikanan Pantai (PPP) Tegalsari Tegal, PPP Bajomulyo Pati, PPP Tasikagung Rembang. Pemilihan lokasi penelitian tersebut dikarenakan berdasarkan hasil pra penelitian yang dilakukan jenis pari kekeh dan pari kikir banyak didaratkan di lokasi ini. Jenis data dan pengambilan data dilakukan dengan cara:
1. Pelingkupan (scoping) di 3 (tiga) lokasi sentra perikanan pari kekeh dan pari kikir di Perairan Utara Jawa. Pengumpulan data dan informasi dilakukan melalui pemetaan pemangku kepentingan kunci, kemudian dilakukan wawancara dan observasi lapangan. Informasi yang dikumpulkan pada pelingkupan tersebut adalah data armada penangkapan (jumlah kapal, ukuran kapal, jenis alat tangkap, ukuran alat tangkap dan jumlah ABK), musim dan daerah penangkapan, pemanfaaatan, distribusi dan pemasaran pari kekeh dan pari kikir.

2. Pencatatan pendaratan pari kekeh dan pari kikir di lokasi Pelabuhan Perikanan Pantai Tegalsari, Tegal; Pelabuhan Perikanan Pantai Bajomulyo, Pati; dan Pelabuhan Perikanan Pantai Tasik Agung Rembang. Pendataan dilakukan setiap hari dengan data yang dikumpulkan adalah jenis spesies pari kekeh dan pari kikir yang ditangkap dengan informasi perikanan seperti informasi alat tangkap, daerah penangkapan. Data tersebut didukung oleh data biologi seperti panjang ikan dan jenis kelamin.

\section{Analisis Data}

Analisis data yang digunakan adalah analisis deskriptif untuk menggambarkan kondisi perikanan pari kekeh dan pari kikir di Jawa Tengah antara lain armada penangkapan, daerah penangkapan ikan pari kekeh dan pari kikir, jumlah hasil tangkapan dan ratarata hasil tangkapan per trip dari setiap kapal yang mendaratkan ikan pari kekeh dan pari kikir menggunakan dengan persamaan (Setyorini et al., 2009):

$$
\text { CPUE }=\frac{\text { EJumlah hasil tangkapan }}{\sum \text { Trip penangkapan }}
$$

Selain itu dilakukan analisis spesies untuk jenis ikan pari kekeh dan pari kikir yang dilakukan baik secara langsung maupun melalui foto yang dikumpulkan dari lapangan. Buku identifikasi yang digunakan adalah Wedgefish and Giant Guitarfish: A Guide to Spesies Identification (Jabado, 2019).

\section{HASIL DAN PEMBAHASAN}

\section{Kondisi Perikanan Pari Kekeh dan Pari Kikir}

Armada penangkapan yang melakukan penangkapan ikan pari kekeh dan pari kikir di PPP Tegalsari Tegal dan PPP Tasik Agung Rembang menggunakan alat penangkapan ikan cantrang sedangkan di PPP Bajomulyo Pati menggunakan alat penangkapan ikan cantrang dan rawai dasar (bottom longline). Ukuran kapal penangkapan ikan pari kekeh dan pari kikir di PPP Tegalsari Tegal yaitu kapal ukuran 50-150 GT dengan jumlah ABK 20-30 orang dan lama trip penangkapan 1,5-2 bulan, sedangkan ukuran kapal di PPP Bajomulyo Pati dan PPP Tasik Agung Rembang yaitu $10-50$ GT dengan jumlah ABK $10-17$ orang dan lama trip penangkapan 15 hari hingga 1 bulan.

Pari kekeh dan pari kikir merupakan hasil tangkapan sampingan dari alat penangkapan ikan 
cantrang maupun rawai dasar (bottom longline). Pari kekeh dan pari kikir hidup di dasar perairan dangkal yang berlumpur (White et al., 2006) sehingga sangat mudah tertangkap oleh alat penangkapan ikan cantrang yang dioperasikan secara aktif menyapu kolom hingga dasar perairan. Pari kekeh yang tertangkap oleh alat tangkap jaring umumnya lebih dari satu individu dan memiliki panjang homogen, hal ini mengidikasikan bahwa ikan pari kekeh tertangkap dalam gerombolan. Sedangkan pari kikir juga tertangkap beberapa kali dengan ukuran yang homogen namun jumlahnya tidak sebanyak pari kekeh.
Berdasarkan informasi dari nelayan yang melakukan penangkapan pari kekeh dan pari kikir, daerah penangkapan ikan (DPI) pari kekeh dan pari kikir yaitu di sekitar perairan Selat Karimata dan Laut Jawa (Gambar 1, Gambar 2 dan Gambar 3). Menurut Last et al. (2016), kawasan perairan Indo-Pasifik merupakan pusat habitat hidup pari kekeh dan pari kikir dengan kelimpahan yang tinggi. Indonesia merupakan salah satu negara yang memiliki perairan dan habitat yang cocok untuk ikan pari kekeh dan pari kikir seperti Perairan Semenanjung Malaka hingga Laut Jawa (Simeon et al., 2019).

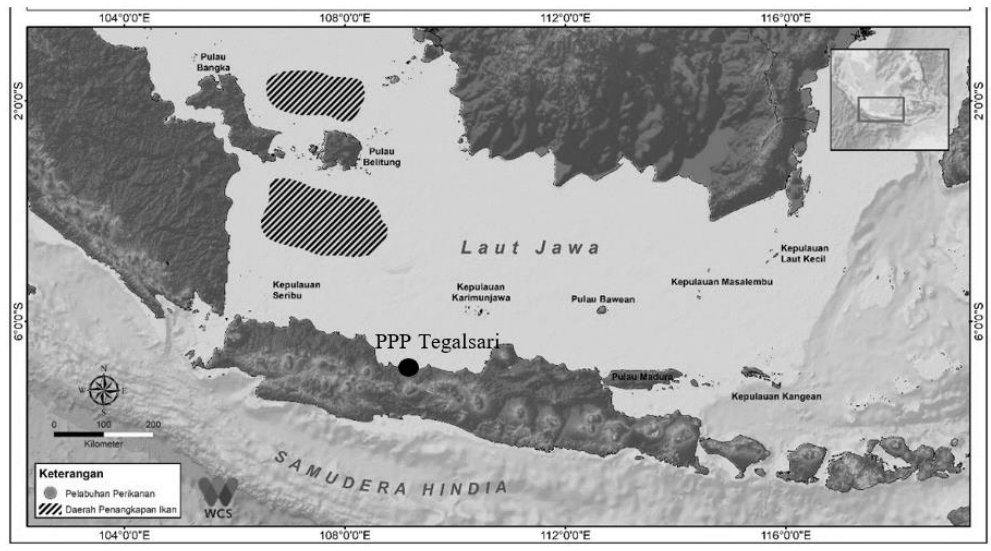

Gambar 1 DPI pari kekeh dan pari kikir nelayan PPP Tegalsari, Tegal.

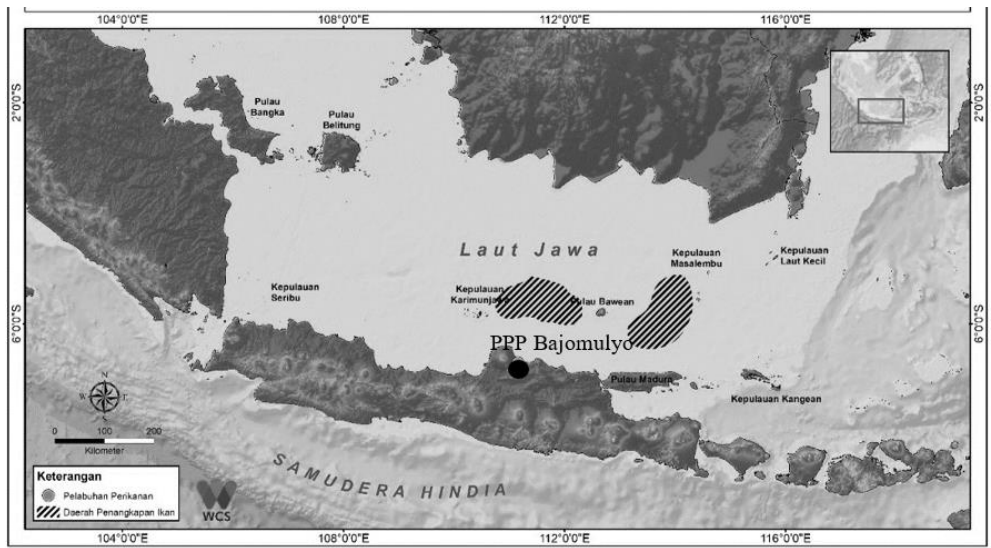

Gambar 2 DPI pari kekeh dan pari kikir nelayan PPP Bajomulyo, Pati.

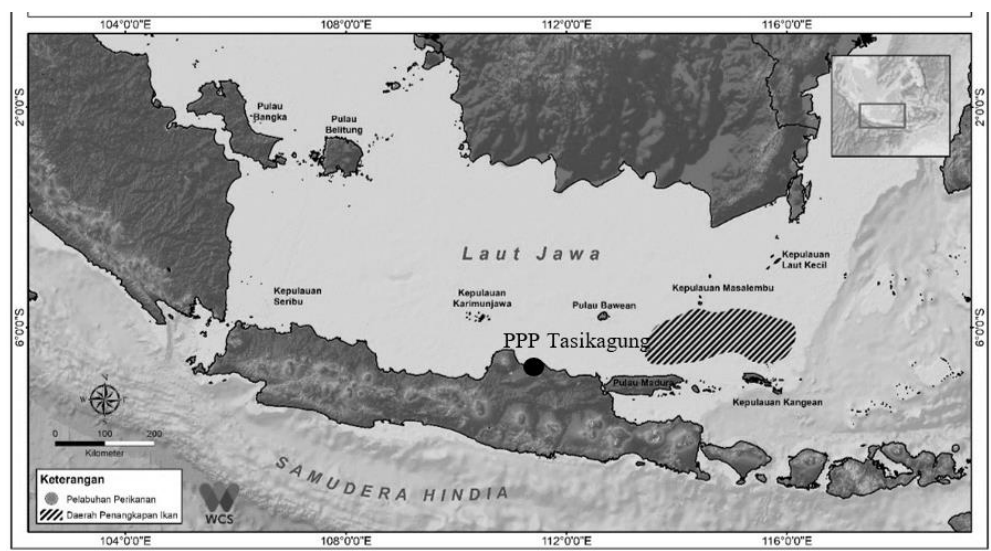

Gambar 3 DPI pari kekeh dan pari kikir nelayan PPP Tasikagung, Rembang. 


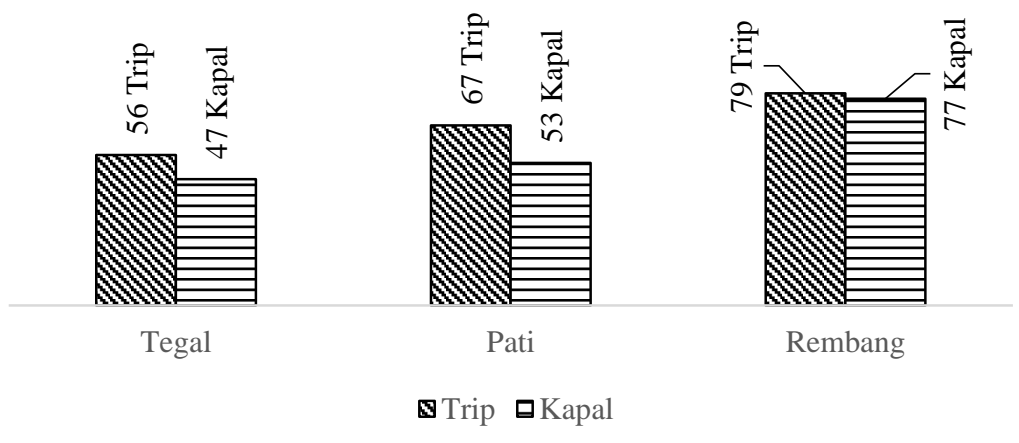

Gambar 4 Jumlah trip dan kapal di tiga lokasi pendataan.

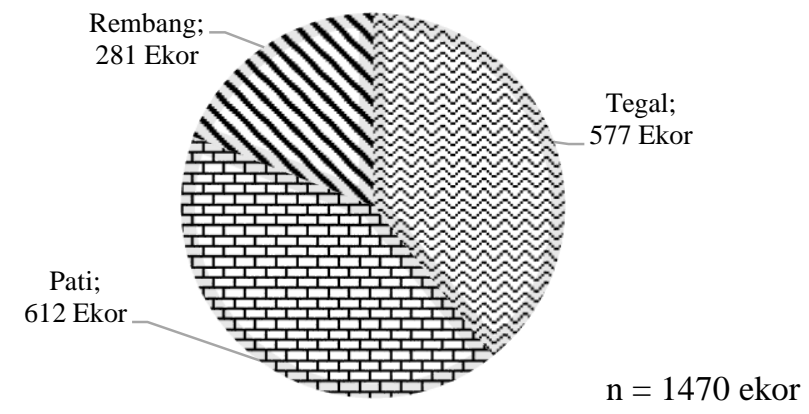

Gambar 5 Total hasil tangkapan ikan pari kekeh dan pari kikir di tiga lokasi pendataan.

Hasil pendataan pendaratan ikan di tiga lokasi selama bulan Mei - Juli 2019, tercatat 202 trip pendaratan dari 177 kapal (Gambar 4) dengan total tangkapan ikan pari kekeh dan pari kikir sebanyak 1470 ekor (Gambar 5). Jumlah trip yang lebih banyak dibandingkan dengan jumlah kapal memiliki arti terdapat kapal yang sama yang mendaratkan lebih dari satu kali pada rentang waktu pengambilan data. Ratarata hasil tangkapan pari kekeh dan pari kikir berdasarkan hasil perhitungan menggunakan rumus (1) dihasilkan bahwa rata-rata hasil tangkapan pari kekeh dan pari kikir di PPP Tegalsari yaitu sebesar 10,3 ekor/trip, PPP Bajomulyo sebesar 9,13 ekor/trip dan PPP Tasikagung sebesar 3,56 ekor/trip. Hal ini menunjukkan bahwa penangkapan ikan pari kekeh dan pari kikir cukup besar yaitu sekitar 22 ekor/trip pada tiga lokasi pendaratan. PPP Tegalsari memiliki hasil tangkapan terbanyak dari setiap tripnya, namun tidak dapat disimpulkan bahwa daerah penangkapan ikan nelayan PPP Tegalsari memiliki kelimpahan lebih tinggil. Banyak hal yang mempengaruhi jumlah tangkapan setiap trip, seperti efektifivitas alat tangkap hingga lokasi pengoperasian alat tangkap.

Jumlah spesies pari kekeh dan pari kikir yang teridentifikasi saat pendataan yaitu sebanyak 6 (enam) spesies yang terdiri dari 4 (empat) spesies ikan pari kekeh dan 2 (dua) spesies ikan pari kikir. Spesies ikan pari kekeh yang teridentifikasi adalah Rhynchobatus australiae, Rhynchobatus laevis, Rhynchobatus springeri dan Rhina ancylostoma. Sedangkan spesies ikan pari kikir yang teridentifikasi adalah Glaucostegus typus dan Glaucostegus thouin (Gambar 6).
Ikan pari kekeh dan pari kikir merupakan jenis ikan pari yang memiliki bentuk menyerupai hiu, memiliki sirip punggung dan sirip ekor. Namun berdasarkan penelitian Zain et al. (2018), penggunaan cytochrome oxidase I (COI) dapat menentukan posisi taksonomi dan dapat membedakan pari kekeh berbeda dengan jenis hiu. Menurut Compagno and Last (2010) spesies ikan pari kekeh Rhynchobatus australiae ditemukan di Perairan Barat Samudra Pasifik, termasuk wilayah Indonesia, Thailand, Philipina dan Australia. Rhynchobatus springeri sebelumnya diidentifikasi sebagai Rhynchobatus djiddensis namun spesies ini ditemukan sebagai spesies yang berbeda pada tahun 2010 (Compagno dan Last 2010). Spesies lain yang ditemukan adalah Rhynchobatus laevis dimana spesies ini tidak tercatat di Indonesia sebelum tahun 2019 (Simeon et al. 2019), hal tersebut dimungkinkan karena sulitnya identifikasi spesies kelompok pari kekeh dengan genus Rhynchobatus. Tantangan dalam identifikasi spesies khususnya jenis ikan pari kekeh yaitu bentuk morfologinya yang mirip akan lebih menyulitkan ketika identifikasi di lapangan. Ikan pari kekeh dapat dibedakan berdasarkan morfologinya namun kemiripan bentuk dan tanda titik putih pada tubuhnya akan menyulitkan saat identifikasi (Compagno \& Last, 2010; Giles et al., 2016). Jenis pari kekeh keempat yang tercatat dalam pendataan adalah Rhina ancylostoma yang sering disebut masyarakat lokal sebagai pari kupu-kupu, pari barong, atau pari batok kelapa, karena bentuk dan tekstur kulitnya yang keras. Di sisi lain informasi biologi pari kikir masih sangat terbatas, sehingga penelitian lanjutan mengenai pari kikir perlu dilakukan. 


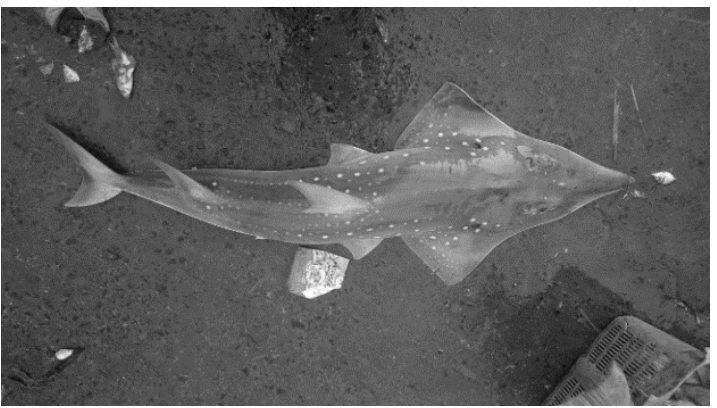

(a)

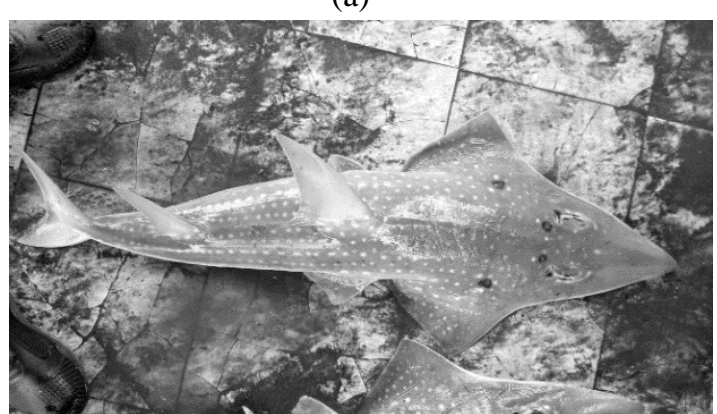

(c)

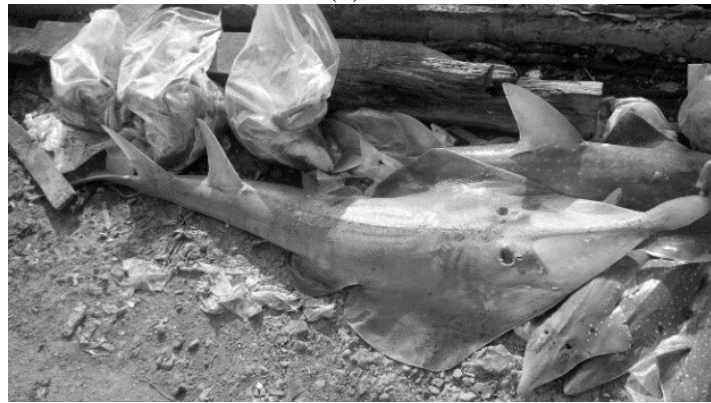

(e)

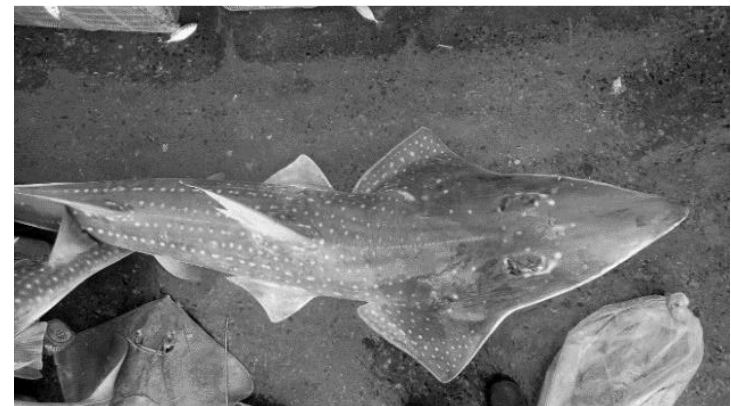

(b)

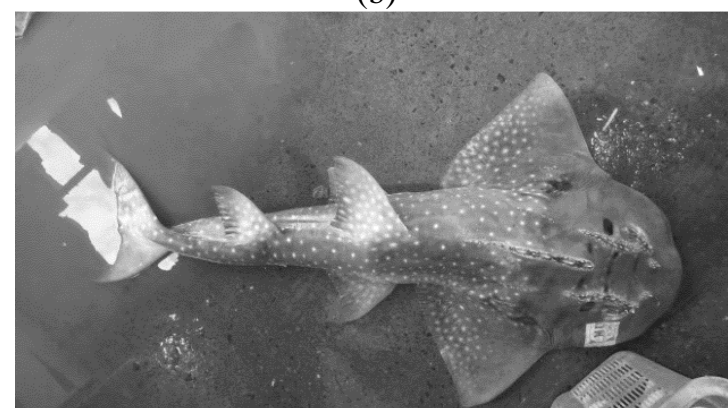

(d)

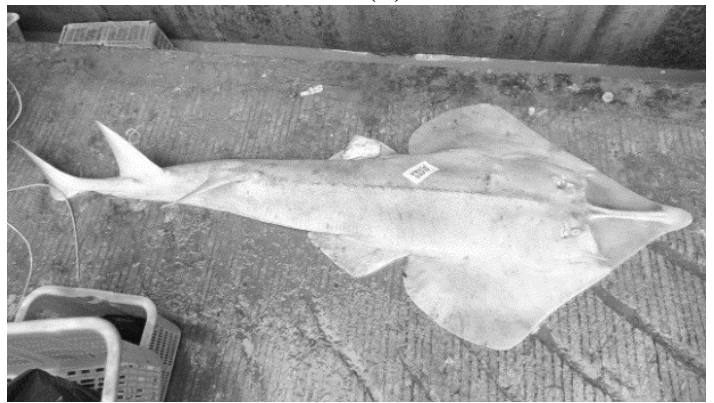

(f)

Gambar 6 Spesies wedgefish dan giant guitarfish yang didaratkan.

(a) Rhynchobatus australiae; (b) Rhynchobatus leavis; (c) Rhynchobatus springeri; (d) Rhina ancylostoma; (e) Glaucostegus thouin; (f) Glaucostegus typus.

Jumlah individu hasil pendataan pendaratan ikan tercatat yang paling dominan adalah spesies Rhynchobatus australiae sebanyak 660 individu, sedangkan yang paling sedikit adalah spesies Glaucostegus thouin sebanyak 51 individu, sebaran jumlah individu yang terdata berdasarkan spesies tersaji pada Gambar 7. Namun demikian, melihat jumlah spesies yang ditemukan pada penelitian ini menunjukkan bahwa keanekaragaman pari kekeh dan pari kikir di daerah penangkapan ikan nelayan cukup tinggi. Jumlah spesies pari kekeh yang ditemukan sebanyak 4 spesies dari 10 spesies yang ada di dunia (Last et al., 2016), dan ditemukan 2 spesies dari 6 spesies yang ada di dunia (Last et al., 2016)

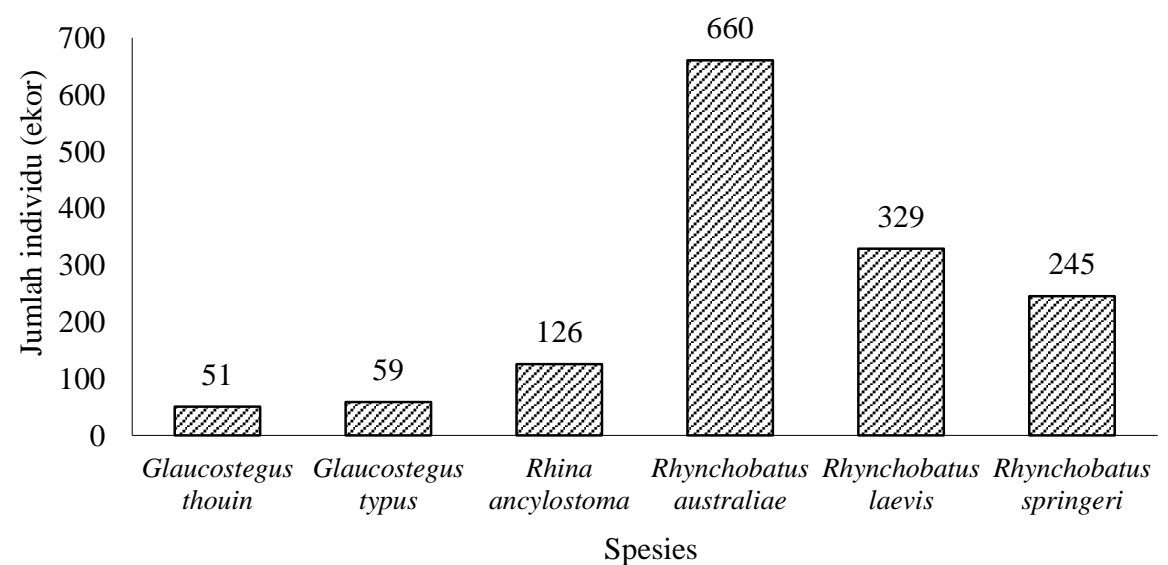

Gambar 7 Sebaran jumlah individu berdasarkan spesies. 


\section{SIMPULAN}

Kesimpulan yang diperoleh berdasarkan hasil penelitian ini adalah alat penangkapan ikan pari kekeh dan pari kikir yang digunakan oleh kapal penangkapan ikan di tiga lokasi pengambilan data adalah cantrang dan rawai dasar, dengan ukuran armada 10 - 150 GT dengan daerah penangkapan sekitar WPP 711 dan WPP 712. Spesies ikan pari kekeh yang ditemukan sebanyak 4 (empat) spesies yaitu Rhynchobatus australiae, Rhynchobatus laevis, Rhynchobatus springeri dan Rhina ancylostoma dan spesies ikan pari kikir yang ditemukan sebanyak 2 (dua) spesies Glaucostegus typus dan Glaucostegus thouin. Hasil tangkapan rata-rata pari kekeh dan pari kikir di PPP Tegalsari sebesar 10,3 ekor/trip, PPP Bajomulyo sebesar 9,13 ekor/trip dan PPP Tasik Agung sebesar 3,56 ekor/trip

\section{SARAN}

Perlu dilakukan penelitian lanjutan mengenai lokasi penangkapan ikan pari kekeh dan pari kikir secara insitu dengan bantuan observer atau sejenisnya, serta perlu juga dilakukan tingkat pemanfaatan komoditas pari kekeh dan pari kikir di Indonesia, khususnya di Jawa Tengah.

\section{UCAPAN TERIMA KASIH}

Terima kasih kepada Dinas Perikanan dan Kelautan Provinsi Jawa Tengah, Kepala PPP Tegalsari, Kepala PPP Bajomulyo dan Kepala PPP Tasikagung atas dukungan dalam riset yang kami lakukan.

\section{DAFTAR PUSTAKA}

Compagno L \& Last P. (2010). A new species of wedgefish, Rhynchobatus palpebratus sp. nov (Rhynchobatoidei: Rhynchobatidae), from the Indo-West Pacific. CSIRO Marine and Atmospheric Research Paper, 32, 77-80.

Dent F \& Clarke S. (2015). State of the global market for shark products. Rome: FAO Fisheries and Aquaculture Technical Paper no 590. 187pp.

[DJPT] Direktorat Jenderal Perikanan Tangkap. (2016). Data Statistik Perikanan Tangkap Menurut Provinsi di Indonesia. Jakarta: Kementerian Kelautan dan Perikanan Republik Indonesia.
Giles J, Riginos C, Naylor RC, Dharmadi D \& Ovenden J. (2016). Genetic and phenotypic diversity in the wedgefish Rhynchobatus australiae, a threatened ray of high value in the shark fin trade. Marine Ecology Progress Series, 548, 165-180.

Jabado RW. (2019). Wedgefishes and Giant Guitarfishes: A Guide to Species Identification. New York: Wildlife Conservation Society. 30 pp.

Last PR, White WT, de Carvalho MR, Sertr B, Stehmann MFW \& Naylor GJP. (2016). Rays of the World. Victoria: CSIRO Publishing.

Mutaqqin E, Simeon BM, Ichsan M, Dharmadi, Prasetyo AP, Booth H, Yulianto I \& Friedman K. (2018). The Scale, Value, and Importance of Non-Fin Shark and Ray Commodities in Indonesia. Rome: FAO. 66pp.

Rahman A, Haryadi J, Sentosa AA \& Mujiyanto. (2017). Kajian Awal Kemunculan Hiu Paus (Rhyncodon typus, Smith 2828) di Teluk Tomoni Dihubungkan dengan Faktor Fisik dan Biologi Perairan. Jurnal Akuatika Indonesia, 2, (2), 128-136.

Setyorini, Suherman A \& Triarso I. (2009). Analisis Perbandingan Produktivitas Usaha Penangkapan Ikan Rawai Dasar (Bottom Set Long Line) dan Cantrang (Boat Seine) di Juwana Kabupaten Pati. Jurnal Saintek Perikanan, 5, (1), 7-14.

Simeon BM, Ichsan M, Muttaqin E, Agustina S, Prasetyo AP, Dharmadi \& Yulianto I. (2019). Laporan Teknis: Profil Perikanan Wedgefish di Indonesia, Studi Kasus di Nusa Tenggara Barat dan Aceh. Bogor: Wildlife Conservation Society Indonesia.

White WT, Last PR, Stevens JD, Yearsley GK, Fahmi, Dharmadi. (2006). Economically Important Shark and Rays Indonesia. Canberra: Australian Centre for International Agricultural Research. 338pp.

Zain BMM, Mutalib SAA, Aifat NR, Masstor NH, Yusuf NSM, Hashim AM, Latiff MABA, Yaakop S, \& Samat A. (2018). Molecular phylogenetic inference of White-Spotted Guitarfish (Rhynchobatus australiae) collected from local Malaysian fish markets. BIODIVERSITAS, 19, (4), 1382-1386. 